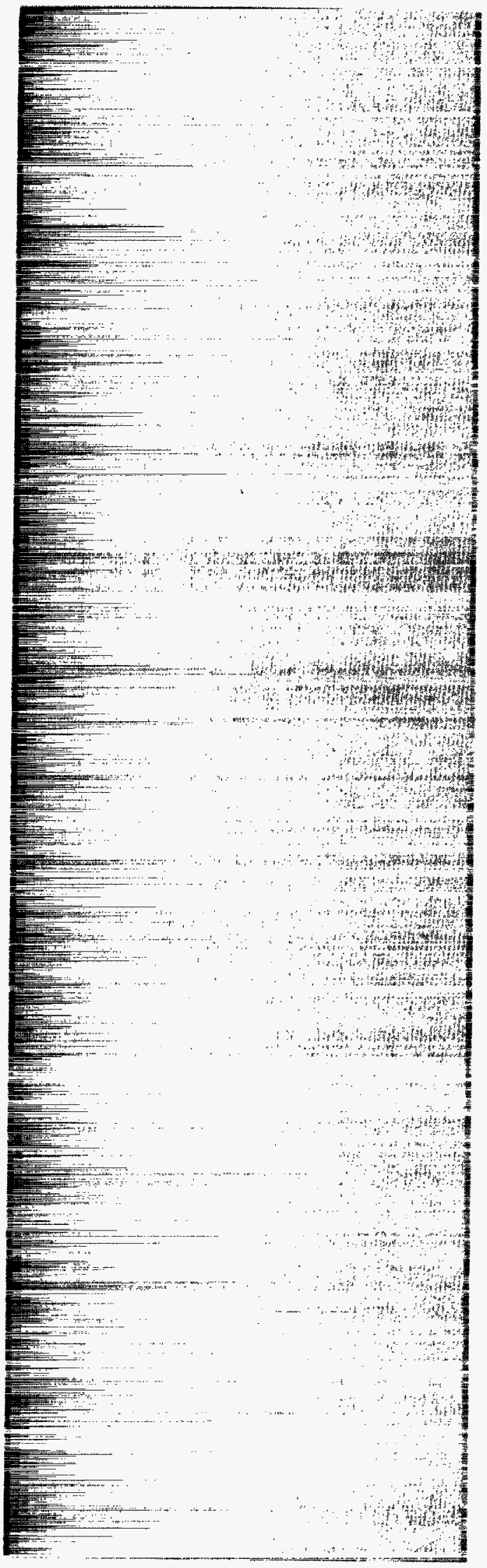

Structural Control on Basaltic Dike and Sill Emplacement, Paiute Ridge Mafic Intrusion Complex, Southern Nevada

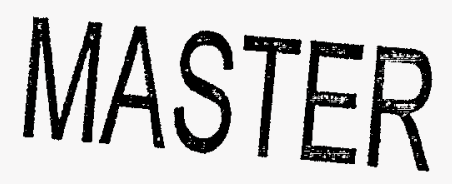

\section{Los Alamos \\ NATIONAL LABORATORY}

Los Alamos National Laboratory is operated by the University of California for the United States Department of Energy under contract W-7405-ENG-36. 
This work is part of the magmatic hazards assessment studies being carried out under the management and funding of the U.S. Department of Energy's Yucca Mountain Site Characterization Project as part of the Civilian Radioactive Waste Management Program.

An Affirmative Action/Equal Opportunity Employer

This report was prepared as an account of work sponsored by an agency of the United States Government. Neither The Regents of the University of California, the United States

Government nor any agency thereof, nor any of their employees, makes any warranty, express or implied, or assumes any legal liability or responsibility for the accuracy, completeness, or usefulness of any information, apparatus, product, or process disclosed, or represents that its use would not infringe privately owned rights. Reference herein to any specific commercial product, process, or service by trade name, trademark, manufacturer, or otherwise, does not necessarily constitute or imply its endorsement, recommendation, or favoring by The Regents of the University of California, the United States Government, or any agency thereof. The views and opinions of authors expressed herein do not necessarily state or reflect those of The Regents of the University of California, the United States Government, or any agency thereof. The Los Alamos National Laboratory strongly supports academic freedom and a researcher's right to publish; therefore, the Laboratory as an institution does not endorse the viewpoint of a publication or guarantee its technical correctness. 
Structural Control on Basaltic Dike and Sill Emplacement, Paiute Ridge Mafic Intrusion Complex, Southern Nevada

Karen E. Carter Krogh

Greg A. Valentine 


\section{DISCLAIMER}

This report was prepared as an account of work sponsored by an agency of the United States Government. Neither the United States Government nor any agency thereof, nor any of their employees, makes any warranty, express or implied, or assumes any legal liability or responsibility for the accuracy, completeness, or usefulness of any information, apparatus, product, or process disclosed, or represents that its use would not infringe privately owned rights. Reference herein to any specific commercial product, process, or service by trade name, trademark, manufacturer, or otherwise does not necessarily constitute or imply its endorsement, recommendation, or favoring by the United States Government or any agency thereof. The views and opinions of authors expressed herein do not necessarily state or reflect those of the United States Government or any agency thereof. 


\section{DISCLAIMER}

Portions of this document may be illegible in electronic image products. Images are produced from the best available original document. 


\title{
STRUCTURAL CONTROL ON BASALTIC DIKE AND SILL EMPLACEMENT, PAIUTE RIDGE MAFIC INTRUSION COMPLEX, SOUTHERN NEVADA
}

by

Karen E. Carter Krogh and Greg A. Valentine

\begin{abstract}
Late Miocene basaltic sills and dikes in the Paiute Ridge area of southern Nevada show evidence that their emplacement was structurally controlled. Basaltic dikes in this area formed by dilating pre-existing vertical to steeply E-dipping normal faults. Magma propagation along these faults must have required less energy than the creation of a self-propagated fracture at dike tips and the magma pressure must have been greater than the compressive stress perpendicular to the fault surface. N- to NE-trending en echelon dikes formed locally and are not obviously attached to the three main dikes in the area. The en echelon segments are probably pieces of deeper dikes, which are segmented perhaps as a result of a documented rotation of the regional stresses. Alternatively, changes in orientation of principal stresses in the vicinity of each en echelon dike could have resulted from local loads associated with paleotopographic highs or nearby structures. Sills locally branched off some dikes within $300 \mathrm{~m}$ of the paleosurface. These subhorizontal bodies occur consistently in the hangingwall block of the dike-injected faults, and intrude Tertiary tuffs near the Paleozoic-Tertiary contact. We suggest that the change in stresses near the earth's surface, the material strength of the tuff and Paleozoic rocks, and the Paleozoic bedding dip direction probably controlled the location of sill formation and direction of sill propagation. The two largest sills deflected the overlying tuffs to form lopoliths, indicating that the magma pressure exceeded vertical stresses at that location and that the shallow level and large size of the sills allowed interaction with the free (earth's) surface.
\end{abstract}

\section{Introduction}

Many studies report that dikes intrude normal to the regional direction of least principal stress, or to the local direction of least principal stress in the vicinity of large structures such as volcanic centers [e.g., Delaney and Pollard, 1981]. Recently, some attention has been given to the mechanics by which those dikes inject into the crust. 
Specifically, it has been suggested that the propagation of dikes occurs by dilation of preexisting fracture surfaces [e.g., Delaney et al., 1986] and by generation of self-propagating tip fractures in advance of the magma [e.g., Rubin, 1993; Lister and Kerr, 1991]. By analyzing the distribution and geometry of dikes and their structural setting, it should be possible to distinguish the dominant emplacement mechanisms and possible structural controls on those mechanisms.

In many cases, subvertical dikes feed subhorizontal sheet intrusions (loosely called sills in this paper, although the strict definition of a sill requires that it be concordant with bedding or foliation of the host rock). Currently, three main factors have been identified that determine whether a dike will feed a sill. (1) If dike propagation is being driven by its buoyancy relative to local wall rocks, then when a dike reaches a height in the lithosphere where its magma is no longer buoyant (the level of neutral buoyancy, or LNB) further upward propagation will cease. Further influx of magma is accommodated by lateral flow at the LNB and depending on whether $\sigma_{3}$ (least principal stress) is horizontal or vertical at the LNB, the dike will become a bladed dike or a sill, respectively [Lister and Kerr, 1991]. (2) The emplacement of a dike changes the stress field because a dike exerts pressure on its walls. Under some conditions [Parsons and Thompson, 1991] the vertical stress could become the least principal stress and sills could form by continued magma influx. This process is enhanced where dikes cross zones of ductile rocks where ambient differential stresses are low, as discussed by Parsons et al. [1992]. (3) If the host rock can behave as a fluid, then fracture propagation ceases and the dike magma simply spreads out laterally at its LNB as a density current. An example of this is where a propagating dike encounters another intrusive body which is still partially molten [Parsons et al., 1992; Valentine, 1993].

The first two factors for sill formation given above, which apply when the host rock behaves as an elastic solid, should have the following trademarks in the field. First, a dike which experiences these processes will likely experience them along most or all of its length. This is because the orientation of the stress field associated with a self-propagating dike can be assumed to be relatively constant at a given level along its plane, except in the immediate vicinity of its edges. Ideally, such a dike would form a sill along its entire length, and the sill would extend outward from both sides of the dike. Second, where a sill forms, its feeder dike should not extend above the level of the sill (except for a minor overshoot distance; Lister and Kerr [1991]). In essence, the entire dike would be deflected horizontally to form a sill. It is worth noting that both of these models for sill formation are most commonly applied to large-scale magma transport problems, for example to explain horizontal reflectors (inferred to be sheet intrusions) at lower-crustal depths that are 
recorded by seismic surveys in extending terrains (see Parsons et al. [1992] for a brief review). Sill formation at smaller scales and shallower depths is not as well understood although it is commonly assumed that these large-scale models apply at all scales. For example, small-scale (tens of meters thick, hundreds of meters in plan dimension) sill formation at the Paiute Ridge intrusive complex, described in this paper, was attributed to an LNB mechanism by Crowe et al. [1983]. By completing a detailed analysis of the distribution and geometries of dikes and sills and their structural setting, it is possible to distinguish the dominant emplacement mechanism(s), thereby providing information about the local and regional stress state and possible structural controls on magma propagation during intrusion.

Here we describe the basaltic intrusive complex at Paiute Ridge, Nevada, which contains both dikes and sills emplaced at shallow depths. However, unlike sills produced by the mechanisms given above, the sills in this complex feed off of short segments of much longer dikes, the sills extend only from one side of their feeder dikes, and the dikes extend significantly higher than the level of sill formation. The role of pre-existing structures on dike and sill formation is emphasized. This area provides a favorable setting in which to document and explain dike and sill emplacement mechanisms because the contact relations are generally well exposed.

\section{Geologic Setting}

The Paiute Ridge intrusive complex is composed of dikes, sills and small remnants of scoria cones and lava flows of alkali basalt (hawaiite) composition (Table 1) (Figure 1). The complex was originally mapped by Byers and Barnes [1967] and has briefly been described by Crowe et al. [1983] and Valentine et al. [1992, 1993]. Paleomagnetic evidence [Ratcliff, 1993; Ratcliff et al., 1994], radiometric age determinations [our data and Byers and Barnes, 1967], and petrologic studies (Perry, 1982) indicate that the basalts were emplaced during a single, brief magmatic pulse that had a total volume of a few tenths of a cubic kilometer. No crosscutting relationships have been found in the intrusions. The ${ }^{40} \mathrm{Ar} /{ }^{39} \mathrm{Ar}$ age of this event is $8.59 \pm 0.07(2 \sigma) \mathrm{Ma}$; it is part of a group of alkali basalts that erupted within the south-central Great Basin in the past $\sim 9 \mathrm{Ma}$, coinciding with the waning of silicic volcanism in the region [Vaniman et al., 1982].

The structural setting at the time of intrusion was that of a small horst and graben system that consisted dominantly of N-to NNW-trending normal faults. These faults, which formed from roughly E-directed extension during the early Tertiary [Minor, 1995], displace a sequence of middle Miocene silicic tuffs, from the Southwestern Nevada Volcanic Field located $25 \mathrm{~km}$ to the west (see Vogel and Byers [1989]; Sawyer et al. 
Table 1. Representative Major Element Oxide Composition of Paiute Ridge Alkali Basalt ${ }^{\mathfrak{a}}$

\begin{tabular}{lc}
\hline \hline Oxide & Weight \% \\
\hline $\mathrm{SiO}_{2}$ & 48.92 \\
$\mathrm{TiO}_{2}$ & 2.84 \\
$\mathrm{Al}_{2} \mathrm{O}_{3}$ & 17.35 \\
$\mathrm{FeO}$ & 10.95 \\
$\mathrm{MgO}$ & 5.28 \\
$\mathrm{CaO}$ & 8.12 \\
$\mathrm{Na} 2 \mathrm{O}$ & 4.17 \\
$\mathrm{~K}_{2} \mathrm{O}$ & 1.70 \\
$\mathrm{P}_{2} \mathrm{O} 5$ & 0.58 \\
& \\
TOTAL & \\
\hline \hline
\end{tabular}

aDetermined by x-ray fluorescence analysis. Sample B-13, reported in Appendix A of Crowe et al. [1986].

[1994]), that had been deposited on rolling hills of Paleozoic carbonates. Eruptive lavas and scoria deposits occur only in the graben regions, whereas dikes and sills occur beneath the original floor. Most of the sills formed within the silicic tuffs (Figure 2) at original depths estimated between $150-250 \mathrm{~m}$ (based on the original topography, as reconstructed from erosional remnants of rocks that overlie the sills).

\section{Descriptions of Dikes and Sills at Paiute Ridge}

\section{Dikes}

Basaltic dikes in the study area have intruded dominantly within a $2 \mathrm{~km}$-wide graben between the Carbonate and Paiute Ridges (Figure 1). The longest dikes occur along pre-existing, NNW-trending, steeply E-dipping normal fault surfaces that cut Paleozoic sedimentary rocks and overlying Tertiary tuffs (Figure 1). There are many other faults in the area, including: (1) those with similar (NNW) strikes that either dip more shallowly east or dip toward the west and; (2) those with E to NE strikes. At the current depth of exposure, however, none of these faults is occupied by dikes. Additionally, there are a few small dikes that radiate out from the volcanic neck (Figure 1) and do not appear to follow pre-existing structures.

The three longest fault-entrenched dikes (PR, $M$ and $E$ on Figure 1) range in length and width from $400 \mathrm{~m}$ to nearly $5 \mathrm{~km}$ and from $1.2 \mathrm{~m}$ to $9 \mathrm{~m}$, respectively. The western- 


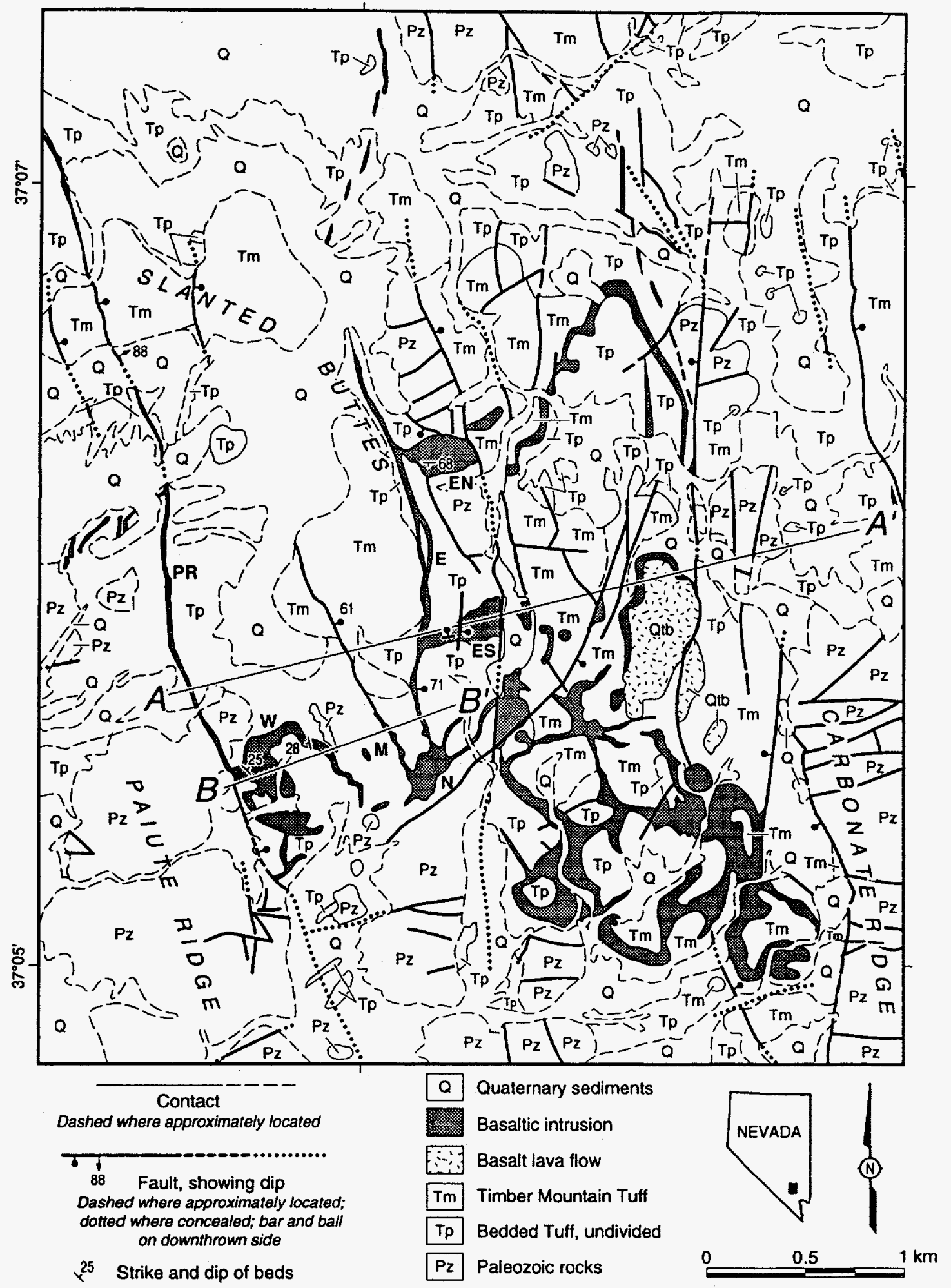

Figure 1. Simplified geologic map of the Paiute Ridge area, emphasizing basaltic rocks. Modified from Goff et al. (1995), Crowe et al. (1983) and Byers and Barnes (1967).

Nomenclature of volcanic units follows Sawyer et al. [1994]. Cross section lines in Figure 2 are indicated. Pz - Paleozoic basement rocks (mainly carbonates) undivided; Tp - undivided bedded tuffs including units belonging to Tunnel Formation, Indian Trail Formation, Paintbrush group, comprised of fallout, pyroclastic flow deposits, and reworked nonwelded tuffs with varying degrees of zcolitic alteration; Tm - Timber Mountain tuffs, undivided (includes Rainier Mesa member); Qac - Quaternary alluvium and colluvium. PR - Paiute Ridge fault and dike; W - W sill; M - M dike and fault; E - E dike and fault; ES - ES sill along E dike near volcanic neck $\mathrm{N}$; EN - EN sill along E dike. 

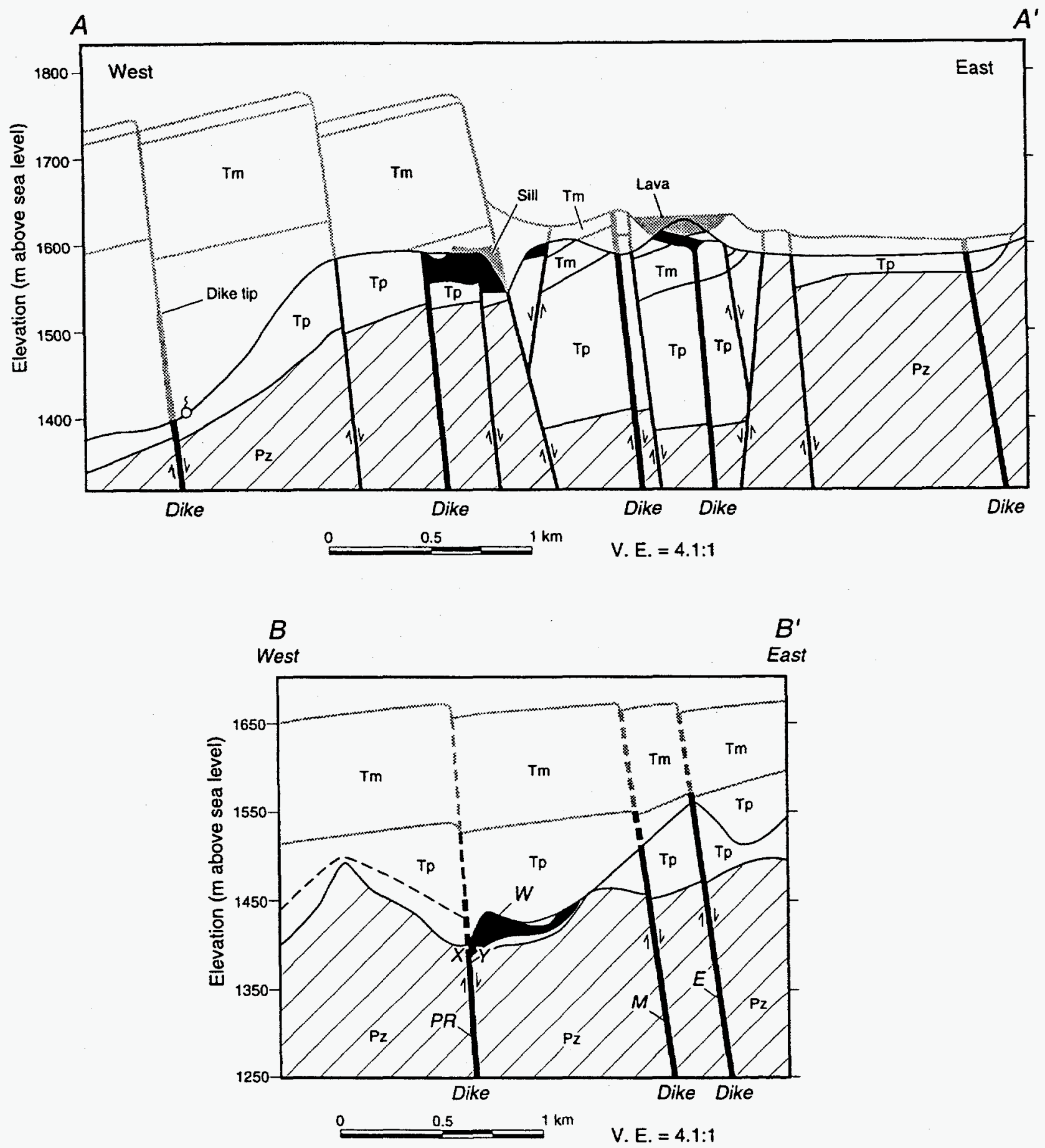

Figure 2. Cross sections through Paiute Ridge area (A-A' and B-B' in Figure 1) showing present day topography and geology, with inferred topography (dashed) at the time of basaltic activity. Letters are the same as in Figure 1. Note that the sills (W sill in B-B' and ES sill in A-A') intrude Tertiary tuffs just above the Tertiary-Cambrian unconformity. X and $\mathrm{Y}$ (of section B-B') represent points at which vertical stresses are unequal (6-7.6 MPa and 5.2 MPa respectively based on estimated overburden; see Interpretation section) within the hangingwall and footwall of the Paiute Ridge fault. 
most, or Paiute Ridge (PR), dike varies in strike from $\mathrm{N}$ to NNW and intrudes Cambrian carbonates (Halfpint member of the Nopah Formation) in the south and nonwelded, bedded Tertiary tuffs ( $\mathrm{Tp}$ in Figure 1) toward the north. The dike visibly occupies the steeply Edipping Paiute Ridge fault at Slanted Buttes (Figure 1) and along the trend of the fault at its southern tip. Along the central segment, the dike does not reside along a mappable fault surface; however, it connects the fault-entrenched tips and most likely occupies a fault surface as well. The dike nowhere appears displaced by the Paiute Ridge fault, which has a throw of less than $15 \mathrm{~m}$ across the Rainier Mesa member at Slanted Buttes. Dike widths are highly variable as they pinch and swell along strike. PR dike is thickest where it feeds the sill at its southern end (Figure 1) and along its longest $(100 \mathrm{~m})$ central segment.

The PR dike is composed of a main continuous dike and at least 24 dike-parallel segments that vary between 4 and $100 \mathrm{~m}$ in length. These segments are isolated and occur within tens of meters of the parent dike. In several places along strike, two segments diverge from the parent dike and enclose a lens of host tuff. In the northern half of the PR dike, where its shallowest intrusion level is preserved at Slanted Buttes, it splits into two parallel dikes and encloses fault breccia. The breccia is in smooth contact with the dike and contains vesiculated basalt and fused tuff. Also at this tip, elongated vesicles in the dike are folded into an open fold with a nearly horizontal axis.

PR dike contains ubiquitous near-vertical joints that result in a pervasive platy texture with plates parallel to the dike-host contact. Conversely, with the exception of local cooling joints in fused wall rock (extending $10-20 \mathrm{~cm}$ into the wall rock, perpendicular to the dike margin), joints are never visible in the host rock along the length of the dike. The contact between basalt and the tuff host rock is consistently smooth and shows no brecciation. Along strike at this contact, the tuff host rock is fused or welded to varying degrees: in places the tuff is completely welded and forms black vitrophyre that grades rapidly away from the contact, over a distance of ca $20-100 \mathrm{~cm}$, into nonwelded tuff that is apparently unaffected by the dike. In other places the tuff is only partly welded at the contact and black fiamme are elongated parallel to the contact. We infer that this "contact welding" is the combined result of heat from the dike and compressive stress exerted by the flowing magma on the wall rocks. Welded host rock commonly contains vesicles that are elongated vertically and parallel to the margin. In some places, welded tuff coats the basalt and displays rills or elongate smooth ridges (flutes). Most rills plunge nearly vertically, however, a sub-horizontal rill is present in the central part of the dike. At the dike tip, exposed at Slanted Buttes, scoria patches crop out near the dike-host contact.

The two eastern dikes, $M$ and $E$ (Figure 1), show geometries and textures similar to those of PR; however, $M$ dike is much shorter and does not feed a sill, and $E$ dike was 
emplaced closest to the paleosurface and feeds two sills. $M$ dike radiates out from a volcanic neck to the southeast (Figure 1) and, although it is poorly exposed, it visibly occupies a normal fault, oriented $\mathrm{N} 40^{\circ} \mathrm{W}, 61^{\circ} \mathrm{E}$, that displaces the Rainier Mesa member and older tuffs (see Byers and Barnes [1967]). M dike varies in width between 2 and $4 \mathrm{~m}$, and has an exposed length of $400 \mathrm{~m}$. Its host rocks are only Tertiary tuffs, which show no brecciation or jointing near the dike contact. Near the neck, $M$ dike is a single continuous dike, and farther from the neck it is composed of several segments. The upper termination of the dike veers west, narrows, and terminates at an elevation of $1579 \mathrm{~m}$. Texture within the dike is characterized by a vertical platy fabric that parallels the dike margins.

$\mathrm{E}$ dike is the eastern-most dike studied within the graben. Like $\mathrm{M}$ dike, it extends from the volcanic neck to the south, and was emplaced into Tertiary tuffs in a N to NNW direction. Near the neck, the dike visibly occupies a NNW-trending, steeply E-dipping normal fault that displaces bedded tuffs $3.5 \mathrm{~m}$ and does not cut the dike. The exposed dike length is $2020 \mathrm{~m}$ and the width varies from $3 \mathrm{~m}$ near the northern tip, to $6 \mathrm{~m}$ near the southern sill. E dike is less segmented than PR dike, and is composed of fewer than a dozen segments. In at least three places near the contact with the Rainier Mesa tuff, (Figure 1), and one location near the volcanic neck, the dike locally diverges to form two segments that engulf an 8 meter wide lens of the tuff host rock.

The texture of $E$ dike is characterized by the pervasive vertical platy fabric common to $\mathrm{M}$ and $\mathrm{PR}$ dikes. Adjacent host tuffs are not jointed nor brecciated, except for local vertical jointing of the Rainier Mesa tuff which is intruded by the dike at its shallowest level. The contact of the dike and host tuff is preserved in places and varies from partly to completely welded in the same manner as described above for the PR dike. Where complete welding has occurred, vesicles are vertical and parallel the dike margin. Contact welding of the host tuffs formed oblate fiamme that parallel the dike-host contact. Visible thermal effects on the wall rocks disappear within one meter of the dike margin.

The southern termination of $E$ dike, near the volcanic neck, shows sub-horizontal rills on the near vertical dike-host contact, while the same contact at the northern termination shows vertical rills. At its northern termination, the dike ends in three leftstepping en echelon segments. The margins of these segments contain completely welded tuff host rock (black vitrophyre) and occasional patches of scoria.

\section{Sills}

Subhorizontal basaltic sheets (here loosely termed sills), that are roughly planar and locally conformable with bedding, have intruded nonwelded bedded tuffs ( $\mathrm{Tp}$, Figure 1) in the graben east of Paiute Ridge. Sills occur consistently as extensions off of fault- 
conforming dikes into the hangingwall block of the NNW-trending normal faults. The sills appear to inject exclusively into tuffs at positions near the contact between the Paleozoic sedimentary rocks and overlying tuffs: the sills do not inject into the Paleozoic rocks themselves.

The western-most sill, W, forms east of PR dike in the hangingwall of the Paiute Ridge fault. It is fed by PR dike, which widens near the sill and can be traced to within about three meters of the sill's western margin. Based on reconstructions (Figure 2), W sill was emplaced in nonwelded bedded tuffs within tens of meters above the presently buried Paleozoic-Tertiary contact. The minimum thickness of $\mathrm{W}$ sill is difficult to determine because of erosion of the uppermost part of the sill and overlying tuffs, but is estimated at about three meters. Its maximum thickness appears to be less than $20 \mathrm{~m}$ and its maximum exposed plan dimension is ca $600 \mathrm{~m}$. The depth of sill intrusion was at most $250 \mathrm{~m}$ below the earth's surface (Figure 2), and $160 \mathrm{~m}$ below the highest level reached by the parent PR dike.

The lower contact of W sill with nonwelded bedded tuffs is generally conformable with bedding as is the upper sill-tuff contact where it is preserved. Textures within the sill are highly variable. At the western margin, the base of the sill has a pervasive platy fabric in which the plates (a few $\mathrm{cm}$ thick) are parallel to the subhorizontal, S-dipping tuff-sill contact. Where this contact is irregular the basalt is either not jointed or has joints that follow the shape of the contact. Above the basal contact, the platy fabric alternates with thicker $(>10 \mathrm{~cm})$ subhorizontal seams of massive basalt. Just north or south of the point where the dike and sill connect, the subhorizontal platy fabric is absent: in two places, 1.5 $\mathrm{m}$ and $10 \mathrm{~m}$ above the basal contact, the basalt is either irregularly vertically jointed, or has a chaotic, jumbled appearance. On the north side of the sill, where the sill and tuff dip on average $44^{\circ}$ toward the south, rills plunging toward $235^{\circ}$ are preserved on the under side of the sill. The margins of the sill dip moderately inward on all sides. Thin, discontinuous sills, $<1 \mathrm{~m}$ thick and $<10 \mathrm{~m}$ long, are locally present beneath the main $\mathrm{W}$ sill; these parallel the main sill and are separated from it by $2-3 \mathrm{~m}$ of country rock.

Two sills, ES and EN, inject into the hangingwall of the fault utilized by E-dike. The sills are fed by $E$ dike which widens near the sill contacts and can be traced directly into the sills. Based on reconstructions (Figure 2), the southern-most sill, ES, injects bedded tuffs (Figure 1) within $15 \mathrm{~m}$ of the presently buried Paleozoic-Tertiary contact. ES is approximately $450 \mathrm{~m}$ in the long dimension and is up to $24 \mathrm{~m}$ thick. The depth of intrusion was probably ca $175 \mathrm{~m}$ below the earth's surface, only $60 \mathrm{~m}$ below the shallowest level attained by the parent dike. 
Along its lower contact with the nonwelded bedded tuffs, ES sill is parallel with the trend of bedding in some places, and is disconformable elsewhere. Tuff host rock underlying the ES sill contains fractures normal to the sill-tuff contact. The fractures typically have sharp lower tips and extend into the host tuff less than 2.5 meters. Through the center of the sill, a set of steeply E-dipping faults, comprising a $\mathrm{N}$-trending normal fault zone, displaces ES sill approximately 4 meters down to the east.

EN, the northern-most sill attached to E dike (Figure 1), is emplaced in nonwelded bedded tuffs just above the Paleozoic-Tertiary contact and continues laterally toward the east to intersect a horst of fractured Ordovician limestones. EN is approximately $380 \mathrm{~m}$ across the long dimension and as much as $46 \mathrm{~m}$ thick. The depth of intrusion was probably less than $100 \mathrm{~m}$ below the earth's surface, at approximately the same height as that attained by the parent dike at its northern tip. EN sill appears generally discordant with bedding of the underlying tuff. Rills exposed on the underside of the basalt in contact with tuff plunge toward $227^{\circ}$ on an EW-striking, $68^{\circ} \mathrm{S}$ dipping surface (Figure 3 ).

\section{En Echelon Segments}

En echelon segmented dikes occur in the area between Paiute Ridge and Carbonate Ridge; however, they were not examined in detail for this study, and so only their gross geometries are mentioned here. The en echelon dikes crop out west of PR dike and north and northeast of $\mathrm{E}$ dike. The two western dikes trend north and northeast and do not follow recognizable pre-existing surfaces such as faults or lithologic contacts. The easternmost en echelon dike trends north, and although it does not inject any pre-existing structures, it does follow the trace of an inferred $\mathrm{N}$-trending fault that terminates south of the dike's southern tip [Byers and Barnes, 1967]. These dikes do not follow the NNW trend of the dikes discussed above, and do not appear to be associated with any sills.

\section{Interpretation}

The three major dikes in the Paiute Ridge region occupy fault surfaces and are not cut by those faults. Thus, the dikes appear to have utilized pre-existing fault surfaces with NNW strikes. This implies that the structurally controlled magma emplacement was energetically more favorable than if the magma had created its own path by fracturing intact rock at the upper dike tip. Sills fed by these dikes intrude into tuffs (except for the distal end of EN sill) and occur consistently in the hangingwall of dike-injected faults, close to and above the Paleozoic-Tertiary contact. The very shallow emplacement of sills (between $250 \mathrm{~m}$ and $100 \mathrm{~m}$ below the paleosurface), and deflection of overlying tuffs, suggests that 


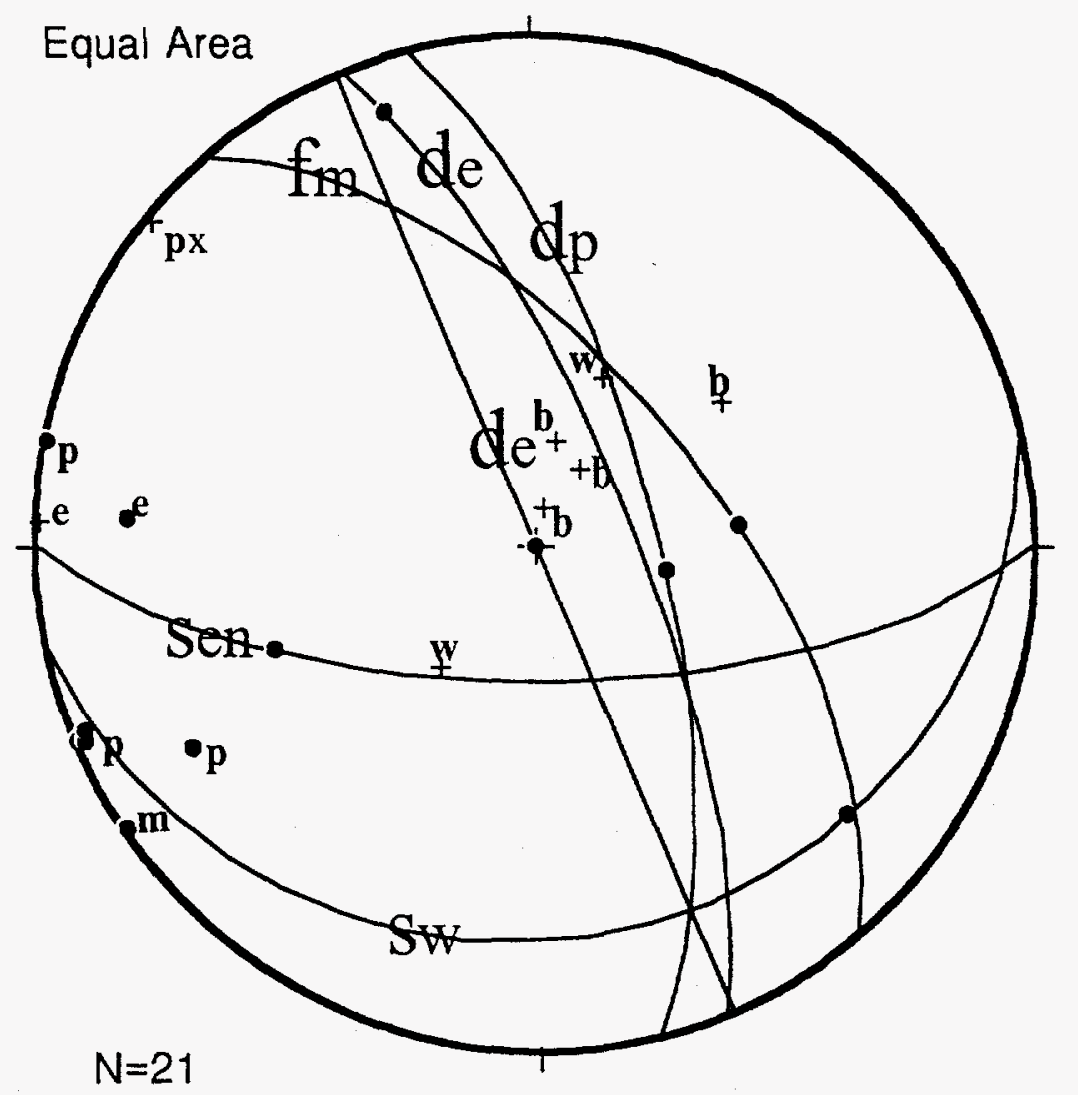

Figure 3. Lower hemisphere stereogram of stuctures at Paiute Ridge. Great circles show surfaces and kinematic indicators: $\mathrm{fm}=$ fault surface confining $M$ dike and slickenside; de $=E$ dike with flow indicator; $\mathrm{dp}=\mathrm{PR}$ dike with flow indicator, Sen = layering in $\mathrm{EN}$ sill, $\mathrm{Sw}=$ layering in $\mathrm{W}$ sill. Isolated dots represent poles to dike orientations: $p=P R$ dike, $e=E$ dike, $m=M$ dike; and + indicate layering: $\mathrm{w}=$ layering in $\mathrm{W}$ dike, $\mathrm{b}=$ layering in tuff adjacent to intrusive bodies, $\mathrm{e}=$ layering in $\mathrm{E}$ dike. The abbreviation $\mathrm{px}$ is an anomalous fabric within PR dike that is perpendicular to its strike. Fabric elsewhere along dikes is coplanar with the dike margin. 
sills interacted with the earth's surface during intrusion. Below, we explore conditions under which such shallow emplacement could occur.

\section{Dikes}

Decades of observations of dike geometries have documented that, in the absence of local stress perturbations, dikes typically form normal to the direction of the least compressive stress, $\sigma_{3}$. More specifically, to propagate a vertical dike, $\sigma_{3}$ must be horizontal and the magma pressure within a dike, $P_{m}$, must exceed $\sigma_{3}[$ Pollard, 1987]. If magma injects a pre-existing plane of weakness, then for a vertical plane, $P_{m}$ must exceed $\sigma_{3}$ and the friction across the crack surface; and for a plane dipping less than $90^{\circ}$, magma pressure in the crack must exceed $\sigma_{3}$ plus a component of the vertical stress, $\sigma_{v}$. Furthermore, if the strike of the pre-existing planes is not normal to the direction of $\sigma_{3}$, magma pressures must be much greater than $\sigma_{3}$ in order to dilate them: Delaney et al., [1986] determined that if $P_{m}$ is only slightly greater than $\sigma_{3}$ or if differential stresses are high [Pollard, 1987], only cracks nearly perpendicular to $\sigma_{3}$ can be dilated. If, on the other hand, $P_{m}$ is greater than the greatest horizontal compressive stress, $\sigma_{H}$, a crack of any orientation can be dilated.

The normal and normal-oblique faults, dilated by dikes, formed between $11.45 \mathrm{Ma}$ and $8.5 \mathrm{Ma}$ under a stress field characterized by a SW- to WSW-directed $\sigma_{3}$ [Minor, 1995]. Subsequent to this faulting event and into present times, the regional stress field underwent a gradual clockwise rotation of $65^{\circ}$ resulting in a NW-directed $\sigma_{3}$ [Haimson et al., 1974; McGarr and Gay, 1978; Minor, 1995]. Basaltic dikes were probably emplaced near the end of the period characterized by the WSW-directed $\sigma_{3}$, before the $65^{\circ}$ rotation, based on following information: (1) The age of the Paiute Ridge basalts is $8.59 \pm 0.07$ $\mathrm{Ma}$, which corresponds to the end of the period of WSW-directed $\sigma_{3}$; and (2) Dikes were emplaced exclusively along NNW-striking faults. If NE-striking faults, and the associated $\mathrm{NW}$-directed $\sigma_{3}$, had existed during the time of intrusion, dikes would have preferentially occupied the NE- rather than NNW-striking faults.

The dikes occupy only steeply dipping $\left(>60^{\circ}\right)$ planes even though other, more shallowly-dipping planes of weakness existed during intrusion: (1) to the south, where the dip of the Paiute Ridge fault shallows to $50^{\circ}$, magma did not inject the fault; and (2) other pre-existing fault surfaces, notably those with shallower or west dips [Byers and Barnes, 1967; Goff et al., 1995], were also not intruded. This suggests that although $P_{m}$ exceeded $\sigma_{3}$. plus a small component of vertical stress, along steeply dipping faults, it was not great enough to overcome the additional component of $\sigma_{v}$ on shallowly dipping faults. 
Some estimates of the physical conditions, such as driving pressure and energy requirements, that accompanied dike intrusion can be made based on the above qualitative analysis. For uniform loading stresses, and neglecting gravitational forces on the solid host rock, magma in a dike does not sense the density of the surrounding rock, but only the ambient stresses on the dike plane [Rubin, 1995]. Therefore, the width to length ratio $(w / l)$ of a dike is related to the pressure available to deform the dike walls and the resistance of the host rock to deformation, [Pollard, 1987; Rubin, 1995] as expressed by:

$$
\frac{w}{l}=\frac{P_{d}}{\mu /(1-v)}
$$

where $P_{d}=P_{m}-\sigma_{3}$ is the driving pressure, $\mu$ is the elastic shear modulus, and $v$ is Poisson's ratio. For the dike intruding the Paiute Ridge fault, the average width is $5 \mathrm{~m}$ and the length is $4.6 \mathrm{~km}$. Estimated average shear modulus and Poisson's ratio for Paleozoic host rocks are $1 \mathrm{GPa}$ and 0.25 , respectively, and for the Tertiary tuffs are $800 \mathrm{MPa}$ and 0.31 [Van Burkirk et al., 1978], respectively. Therefore, the driving pressure for the basaltic magma in these dikes was probably on the order of 1.4 to $2.6 \mathrm{MPa}$, which is within the range of 1 to $4 \mathrm{MPa}$ reported by others [e.g., Pollard, 1987]. These low driving pressures might be the reason some of the dikes apparently did not intersect the earth's surface. Such insufficient pressures could have occurred for many reasons, including a decreasing magma supply with time, inhibited flow due to solidification of the magma, or lateral redirection of the magma into adjacent sills.

From these driving pressures, we can obtain a measure of the energy consumed in the fracture process associated with dike intrusion. $G$ is the mechanical energy release rate per unit increase in crack length. The propagation path of a dike will be that which minimizes G [Delaney et al., 1986; Rubin, 1995]. The amount of energy required to propagate the dike can be determined by assessing the critical energy release rate, ${ }^{1} G_{C}$, using Equation 21 of Pollard (1987):

\footnotetext{
${ }^{1}$ Note that $\mathrm{K}=\mathrm{Kc}$ is a commonly used proprogation criterion; however, its use in cases such as this is questionable. Rubin (1993) has shown that the stress intensity factor, $\mathrm{K}$, which is a measure of the stresses at the crack tip, cannot be considered solely a material property, but in fact, varies with confining pressure and thus is not a physically meaningful quantity. Additionally, the use of $\mathrm{K}=\mathrm{Kc}$ as a propagation criterion is valid only if the region of inelastic deformation is small compared to crack length (see Rubin, 1995). For many dikes, zones of inelastic deformation at the dike tip are long, and a significant amout of energy could be dissipated by mechanisms other than simple extension of a crack surface (see Shlyapobersky and Chudnovsky, 1994). As such, if $\mathrm{K}=\mathrm{Kc}$ is inadequate to determine conditions necessary for propagation, it is preferable to analyze the energy requirements of the system through the criterion Gc because of its ability to incorporate the effects of the host rock as in addition to the crack configuration and loading.
} 


$$
G_{c}=\frac{\pi l P_{\alpha}^{2}(1-v)}{4 \mu}
$$

Using the parameters specified above in Eq. (1), $G_{C}$ is approximately $6 \mathrm{MPa} \cdot \mathrm{m}$ for dikes that intruded intact rock. This value must be greater than the critical energy release rate for dilating a pre-existing plane of weakness because the latter does not require the additional energy needed to fracture intact rock at the dike tip. In other words, for dikes at Paiute Ridge, it was energetically more favorable for magma to utilize pre-existing fault surfaces than to create new fractures in intact rock, and so $G_{\mathcal{C}}$ can be used as an estimate of the minimum energy required for dikes to form by fracturing of intact rock and a maximum of that required for injecting pre-existing planes. At present, few other values of $G_{C}$, for dike formation, have been published. It will be interesting to compare energy requirements for different intrusion scenarios as they become available.

Flutes and rills on the dike-host rock contact can be interpreted as flow direction indicators. Such features observed in PR dike are dominantly vertical and therefore indicate vertical flow. No such features were observed in $\mathrm{M}$ dike. Indicators in $\mathrm{E}$ dike suggest that flow in the northern part of the dike was dominantly vertical, while toward its southern end flow was lateral. We suggest that the dike was emplaced first by flowing up along a fault plane. Flow gradually became focused at the southern end of the dike to form the volcanic neck or plug. As this conduit became established, magma flowing up the southern end of the dike was diverted toward the conduit, resulting in lateral flow indicators. As the conduit was established it exerted pressure on its walls. Because of its roughly cylindrical shape, this pressure resulted in tension on the conduit walls and the formation of radial dikes (Figure 1). One of these radial dikes was "captured" by a preexisting fault as it propagated away from the plug to form $\mathbf{M}$ dike. This sequence of events, where magma rises in a dike but gradually becomes focused into a central conduit is very common for basalts [e.g., Richter et al., 1970; Delaney and Pollard, 1981; Bruce and Huppert, 1990].

\section{Sills}

Sill geometries and spatial distributions in the Paiute Ridge area suggest that the recently proposed mechanisms for sill formation, (i.e., along the level of neutral buoyancy or LNB [Lister and Kerr, 1991] or at the point of dike induced stress reorientation [Parsons et al., 1992; Parsons and Thompson, 1991]), do not adequately explain their existence. The buoyancy force in an LNB mechanism depends on the integrated density of vertical columns through the dike and through adjacent wall rock to the surface, not on the local 
density contrast between magma and immediately adjacent wall rock. With this in mind, it seems unlikely that an LNB mechanism could have acted along such localized segments of the main dikes. In addition, along most of the dikes' lengths, there is evidence that magma continued to rise to a level significantly higher than the sills, and, the sills propagated from only one side of the dikes. Similar arguments can be made against the mechanism of dikeinduced stress reorientation [Parsons et al., 1992; Parsons and Thompson, 1991] for sills at Paiute Ridge. This mechanism would most likely have caused sills to form along most of the length of a dike, barring any externally (i.e., non-dike related) induced major stress heterogeneities along the length of the dike.

Considering that the magma senses and responds to the ambient stresses, the sills must have intruded at levels where the maximum vertical stress was lower than the maximum compressive horizontal stress. Additionally, at the point of injection, the magma pressure must have exceeded either the strength of the rock or the cohesive strength of a subhorizontal pre-existing plane of weakness, such as a bedding plane or lithologic contact, and also must have exceeded the vertical stresses at the level of sill injection $(<300 \mathrm{~m})$. Vertical stresses at this depth can be estimated, (using $\sigma_{v}=\rho g h$ ), at roughly $5.2 \mathrm{MPa}$ in the Tertiary tuffs, and ca $6.5 \mathrm{MPa}$ under the estimated volume of Cambrian rocks. Therefore, $P_{m}$ for the tuff-intruding sills must have been greater than 5.2 MPa. In the absence of any tectonic compression, vertical stresses exceed horizontal stresses at all depths below the earth's surface (see Figure 4 and compare $\sigma_{v}=\rho g h$ with $\sigma_{h}=(v / 1-v) \rho g h$ ). For conditions to have favored sill formation, then, some additional horizontal compressive stress must have existed along segments of $P R$ and $E$ dikes at points where the sills formed: if a small ( 3 to $4 \mathrm{MPa}$ ) horizontal stress had existed, the horizontal stresses would have exceeded the vertical stresses at depths shallower than $300 \mathrm{~m}$ (Figure 4). We suggest, therefore, that a horizontal compressive stress existed during sill formation along at least short segments of the dike-hosting faults. Such a stress regime would be similar to that reported for present-day horizontal stresses at a depth of $380 \mathrm{~m}$ near Paiute Ridge: Haimson et al. [1974] report in situ stresses that range from 8.8 (NE-directed $\sigma_{l}$ ) to 2.4 $\mathrm{MPa}$ (NW-directed $\sigma_{3}$ ), so the magnitude of compressive stress that we infer is reasonable. We emphasize, though, that because the sills formed only along very short segments of the dikes and their host faults, this compression was probably localized. This local phenomenon might be due to contrasting rock properties on different sides of the faults and/or local stress variations due to topographic effects.

If, indeed, ambient stresses are the dominant factor controlling the direction and geometry of magma injection, the consistency with which sills inject into a particular structural setting (into Tertiary tuffs within the hangingwalls of faults, just above the 


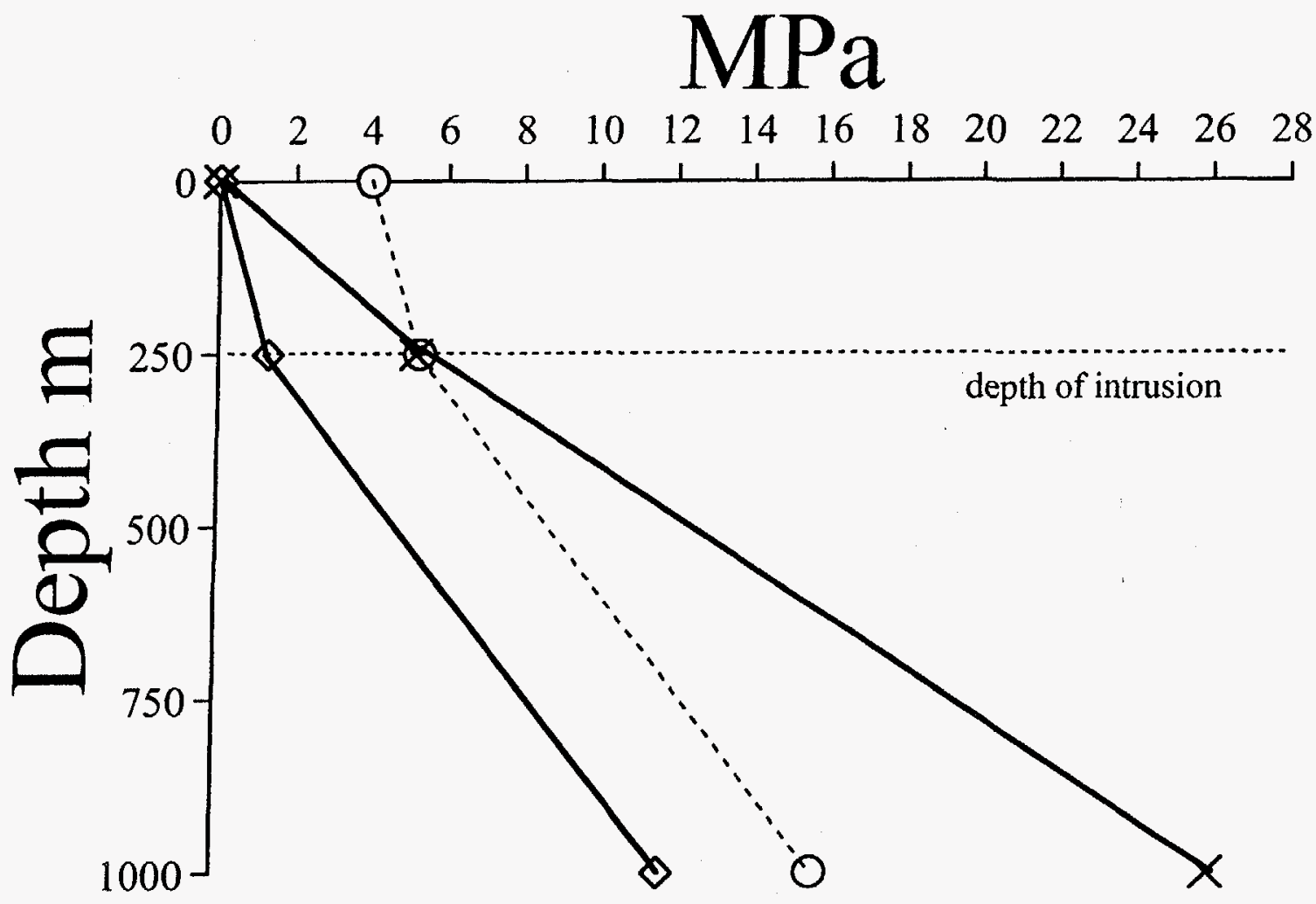

Figure 4. Possible stress gradients for conditions during intrusive activity in the Paiute Ridge area. Depth is from paleosurface. Diamond = horizontal stress, $\mathrm{X}=$ vertical stress, and circle $=$ horizontal stress + tectonic compression. Intrusion of sills would be favored at the depth where the vertical stress is less than the horizontal stress. With a small tectonic compression ( $4 \mathrm{MPa})$ the horizontal stress can exceed the vertical stress at depths shallower than approximately $300 \mathrm{~m}$ (depth $=250 \mathrm{~m}$ is approximate Tertiary-Paleozoic boundary). Calculations for the vertical and horizontal stresses are standard (see e.g., Engelder [1993]). Rock properties are described in the text. 
contact with Cambrian carbonates), must be related to stresses in the vicinity of parent dikes. Magma migrating upwards along dikes would approach such a contact ( $T$ Cambrian) and sense a drastic change in ambient stresses and a difference in those stresses on either side of the fault: vertical stresses on the western side of PR dike would have been roughly 6 to $7.6 \mathrm{MPa}$ in Cambrian carbonates (at about $250 \mathrm{~m}$ depth) and those on the eastern side, in Tertiary tuffs, would have been about 5.2 MPa (Figure 2). Furthermore, adjacent to PR dike, bedding planes are W-dipping in both the Cambrian and Tertiary rocks. The dip direction of these potential planes of weakness would favor the injection of sills upwards toward the east, rather than downwards towards the west (Figure 2) similar to the fluid-filled cracks that seek the earth's surface analyzed by Weertman [1980]. Based on an analogous structural setting, it is likely that the same mechanical configuration controlled the injection of the two sills fed by E dike. Thus, the consistent occurrence of sills in particular geometric situations that are highly spatially localized, suggests that their emplacement is controlled by the ambient stresses and rock type. These two factors were highly variable during intrusion because of the spatial distribution and orientation of tuff, Paleozoic rocks (that also formed paleo-hills), and major faults.

W sill and the largest sill near Carbonate Ridge (Figure 1) have deflected the overlying tuffs and dip inward around their margins to form lopoliths. The collapsed top of these bodies suggests that the magma interacted with the overlying free (earth's) surface. This geometry is not shared by the two smaller sills (ES and EN) fed by E dike. We suggest, following results of the laccolith study by Pollard and Holzhausen [1979], that the size of the sills is an important factor in the formation of the lopolithic geometry at Paiute Ridge. Pollard and Holzhausen [1979] suggest that, because of tensile stresses over the central part of a sill, a large body of magma will interact with the earth's surface if it is close to the surface. We suggest that the same physical constraints control the formation of lopoliths: larger bodies that are closer to the earth's surface experience more interaction (i.e., bending of overlying strata) with that surface. Pollard and Holzhausen [1979] calculate that the transition from a sill to a laccolith occurs at a ratio of half-length to depth ( $l / d$ ) of approximately 1.6. We support this theory with the ratios for lopoliths in the Paiute Ridge area: the $l / d$ of $\mathrm{W}$ sill is between 1.2 and 1.88 (depending on the estimated depth); the $l / d$ of the largest sill is approximately 8.5 . The smaller sills are not lopoliths and have l/d ratios between 1 and 2. Notably, these sills have a much smaller area than the lopoliths, and therefore could not exert as much force on the overlying rocks to cause bending. Therefore, the aerial extent of the sill, in addition to simply the $l / d$ ratio, must also be an important factor in whether it becomes a laccolith or lopolith. There are two reasons why the roofs of Paiute Ridge intrusions sag inward (forming lopoliths) rather than 
bow upward: (1) The magma may have been vesicular at these shallow depths during intrusion, so that while magma initially pushed the roof up, as the volatiles leaked out and the intrusion cooled the roof gradually sagged downward. (2) The host rocks were originally nonwelded silicic tuffs, but the heat and pressure of the intrusions caused welding, pore collapse, and attendant decrease in rock volume adjacent to the intrusions. This accounts for inward sagging of both the roofs and floors of the lopoliths.

\section{En Echelon Dikes}

The mechanisms responsible for the formation of the en echelon dikes at Paiute Ridge are not known, but based on their geometries and the stress history, we offer two possible models. The trend of the line connecting the en echelon segments varies from $\mathrm{N}$ to $\mathrm{NE}$, in contrast to the NW-trending dikes discussed previously. It is possible that these segments represent intrusion during the transition from the SSW- to NW-directed $\sigma_{3}$ around $8.5 \mathrm{Ma}$ (see above). If these dikes intruded during a rotating stress field, their orientation would reflect a plane normal to the direction of the incremental $\sigma_{3}$ as it changed from SSW to NW. Additionally, the rotation of principal stresses about an axis parallel to the propagation direction of the dike, as described by Delaney and Pollard [1981] and Pollard [1987], could have resulted in segmentation of those dikes. In the Paiute Ridge area, rotation would have been clockwise about a vertical axis near the final extent of dike ascension (at depths $<250 \mathrm{~m}$ ), resulting in right-stepping $\mathrm{N}$-trending segments of $\mathrm{NE}$ trending dikes (Figure 1). Alternatively, if the en echelon dikes formed in the same (nonrotating) stress field as did the other non-segmented dikes, it is possible that surficial loads could be responsible for the near-surface segmentation. Structures, topographic relief, or intrusive bodies near the intruding dikes, could have induced a rotation of local principal stresses, resulting in dike segmentation. It is possible that further age constraints could reveal which of the two models is most likely.

\section{Conclusions}

The location and geometry of Miocene basaltic intrusive bodies in the Paiute Ridge area are strongly controlled by pre-existing structures and regional stresses. The longest dikes intruded normal to $\sigma_{3}$, along pre-existing faults with critical dips and strikes: only NNW steeply dipping planes were injected. To achieve this geometry, magma pressures must have been greater than $\sigma_{3}$, and also have exceeded friction across the fault surfaces. Driving pressures were apparently not sufficient to intrude along faults of other orientations nor along self-propagated paths. En echelon dikes trend at an angle to the fault-conforming dikes, and could have formed during the documented $65^{\circ}$ stress-field rotation after ca 8.5 
Ma. Sills, which occur adjacent to dikes within $300 \mathrm{~m}$ of the paleosurface, consistently occur in the hangingwall block of the dike-injected faults. We interpret their location in Tertiary tuffs, just above the Paleozoic-Tertiary contact, to indicate that intruding magma sensed a significant local change in ambient stresses along the fault planes. Additionally, we suggest that the dip of bedding surfaces helped localize the direction of sill injection: magma preferred to flow upwards towards the east rather than downward toward the west. The two largest sills formed lopoliths indicating that the magma pressure exceeded the vertical stresses at that location and that the shallow level and large aerial extent of the sills allowed interaction with the free (earth's) surface. We infer that sills at depths greater than those now exposed at the surface, would be less likely to form lopoliths, and that they would preferentially form in the Tertiary tuffs rather than in the Paleozoic sedimentary rocks. Finally, we speculate that the processes that governed dike propagation and local shallow sill formation at Paiute Ridge may operate in other shallow rift settings (e.g. continental rifts and rift zones of shield volcanoes, as have recently been addressed by Johnson [1995] who notes the importance of structure-related stress variations in stalling dikes in the east rift zone at Kilauea volcano).

\section{Acknowledgments}

This work is part of magmatic hazards assessment studies being carried out under the management and funding of the U.S. Department of Energy's Yucca Mountain Site Characterization Project as part of the Civilian Radioactive Waste Management Program. This research (for KECK) was also supported in part by an appointment to the U.S. Department of Energy Distinguished Postdoctoral Research Program sponsored by the U.S. Department of Energy, Office of Science Education Programs, and administered by the Oak Ridge Institute for Science and Education. Artwork in the paper is by Andrea Kron. We thank Frank Perry, Bruce Crowe, Paul Delaney, and Allan Rubin for helpful discussions, and Fraser Goff for collaboration in the field and recognizing a new fault. 


\section{References}

Bruce, P. M, and H. E. Huppert, Solidification and melting along dykes by the laminar flow of basaltic magma, in Magma Transport and Storage, edited by M. P. Ryan, pp. 87-101, John Wiley \& Sons Ltd., 1990.

Byers, F. M., and H. Barnes, Geologic Map of the Paiute Ridge Quadrangle, Nye and Lincoln Counties, Nevada, U.S. Geol. Surv. Quad. Map GQ-577, 1967.

Crowe, B. M., Self, S., Vaniman, D., Amos, R., and F. Perry, Aspects of potential magmatic disruption of a high-level radioactive waste repository in southern Nevada, $J$. Geol., 91, 259-276, 1983.

Crowe, B. M., K. H. Wohletz, D. T. Vaniman, E. Gladney, and N. Bower, Status of volcanic hazard studies for the Nevada Nuclear Waste Storage Investigations. Los Alamos National Laboratory Report, LA-9325-MS, vol. II, 1986.

Delaney, P. T., and D. D. Pollard, Deformation of host rocks and flow of magma during growth of minette dikes and breccia-bearing intrusions near Shiprock, New Mexico, U.S. Geol. Surv. Prog. Pap., 1202, 61 pp., 1981.

Delaney, P. T., Pollard, D. D., Ziony, J. I., and E. H. McKee, Field relations between dikes and joints: Emplacement processes and paleostress analysis, J. Geophys. Res., 91, 4920-4938, 1986.

Engelder, T., Stress Regimes in the Lithosphere, Princeton Univ. Press, 1993.

Goff, F., WoldeGabriel, G., Warren, R., and K. E. Carter Krogh, Geologic Map, PaiuteRidge-Slanted Buttes, Half-Pint Range, Nevada, Los Alamos National Laboratory Report, in press, 1995.

Haimson, B. C., Lacomb, J., Jones, A. H., and Green, S. J., Deep stress measurements in tuff at the Nevada Test Site, in Advances in Rock Mechanics, v. IIa, pp. 557-561, Nat. Academy Sci., Washington D.C., 1974.

Johnson, D. J., Molten core model for Hawaiian rift zones, J. Volcanol. Geotherm. Res., 66, 27-35, 1995.

Lister, J. R., and R. C. Kerr, Fluid-mechanical models of crack propagation and their application to magma transport in dykes, J. Geophys. Res., 96, 10,049-10,077, 1991.

McGarr, A., and Gay, N. C., State of stress in the earth's curst, Ann. Rev. Earth Planet. Sci., 6, 405-436, 1978.

Minor, S. A., Superposed local and regional paleostresses: Fault-slip analysis of Neogene extensional faulting near coeval caldera compleses, Yucca Flat, Nevada, J. Geophys. Res., 100, 10507-10528, 1995.

Parsons, T., and G. A. Thompson, The role of magma overpressure in suppressing earthquakes and topography: Worldwide examples, Science, 253, 1399-1402, 1991. 
Parsons, T., Sleep, N. H., and G. A. Thompson, Host rock rheology controls on the emplacement of tabular intrusions: Implications for the underplating of extending crust, Tectonics, 11, 1348-1356, 1992.

Perry, F. V., Los Alamos National Laboratory, unpublished data, 1982.

Pollard, D. D., and G. Holzhausen, On the mechanical interaction between a fluid-filled fracture and the earth's surface, Tectonophys., 53, 27-57, 1979.

Pollard, D. D., Elementary fracture mechanics applied to the structural interpretation of dykes, in Mafic Dyke Swarms, Geol. Assoc. Can. Spec. Pap. 34, edited by H. C. Halls and W. H. Fahrig, pp. 5-24, 1987.

Ratcliff, C. D., Paleomagnetic and rock magnetic study of the Paiute Ridge subvolcanic center, southern Nevada, unpub. M.S. Thesis, Univ. New Mexico, 69 pp., 1993.

Ratcliff, C. D., Geissman, J. W., Perry, F. V., Crowe, B. M., and P. K. Zeitler, Paleomagnetic record of a geomagnetic-field reversal from late Miocene mafic intrusions, southern Nevada, Science, 266, 412-416, 1994.

Richter, D. H.; Eaton, J. P.; Murata, K. J.; Ault, W. U.; and H. L. Krivoy, Chronological narrative of the 1959-1960 eruption of Kilauea Volcano, Hawaii, U.S. Geol. Surv. Prof. Pap. 537-E, p. E1-E73, 1970.

Rubin, A. M., Tensile fracture of rock at high confining pressure: Implications for dike propagation, J. Geophys. Res., 98, 15919-15935, 1993.

Rubin, A. M., Propagation of magma-filled cracks, Ann. Rev. Earth. Planet. Sci., 23, 287-336, 1995.

Sawyer, D. A., R. J. Fleck, M. A. Lanphere, R. G. Warren, D. E. Broxton, and M. R. Hudson, Episodic caldera volcanism in the Miocene southwestern Nevada volcanic field: Revised stratigraphic framework, ${ }^{40} \mathrm{Ar} /{ }^{39} \mathrm{Ar}$ geochronology, and implications for magmatism and extension, Geol. Soc. Am. Bull., 106, 1304-1318, 1994.

Shylapobersky, J., and Chudnovsky, A., 1994. Review of recent developments in fracture mechanics with petroleum engineering applications, Proc. Euroch Symposium on Rock Mechanics in Petroleum Engineering, p. 381-389.

Valentine, G. A., Note on the distribution of basaltic volcanism associated with large silicic centers, J. Volcanol. Geotherm. Res., 56, 167-170, 1993.

Valentine, G. A., Crowe, B. M., and F. V. Perry, Physical processes and effects of magmatism in the Yucca Mountain region, Proc. 1992 Conf. High Level Rad. Waste Management, American Nuclear Society, pp. 2014-2024, 1992.

Valentine, G. A., Groves, K. R., Gable, C. W., Perry, F. V., and B. M. Crowe, Effects of magmatic processes on the potential Yucca Mountain respository: Field and 
computational studies, Proc. Focus '93 Site Characterization Model Validation, American Nuclear Society, pp. 167-173, 1993.

Van Burkirk, R. G., Gardiner, D. S., and S. W. Butters, Characterization of Yucca Flat materials, Terra Tek Report 78-67, Salt Lake City, Utah, Terra Tek Inc., 1978.

Vaniman, D. T., Crowe, B. M., and E. S. Gladney, Petrology and geochemistry of hawaiite lavas from Crater Falt, Nevada, Contrib. Mineral., Pertol., 80, 341-357, 1982.

Vogel, T. A., and F. M. Byers, Introduction to the Special Section on the Southwestern Nevada Volcanic Field, J. Geophys. Res., 94, 5907, 1989.

Weertman, J., The stopping of a rising, liquid-filled crack in the earth's crust by a freely slipping horizontal joint, J. Geophys. Res., 85, 967-976, 1980. 